\title{
Studies on the deflocculants of ${ }_{66}$ dialkyldithiophosphate group

Negoro, Kenji* Akamatsu Sumio** and Kitawaki Hideo*

The Faculty of Engineering, Hiroshima University*

Asahi Dyestuff Manufactory**

\section{abstracts}

Dialkyldithiophosphate were obtained from aliphatic alcohol (e.g. Iso-PrOH, $n-\mathrm{BuOH}, n-\mathrm{C}_{12} \mathrm{H}_{25}$ $\left.\mathrm{OH}, \mathrm{n}-\mathrm{C}_{18} \mathrm{H}_{37} \mathrm{OH}\right)$ and $\mathrm{P}_{2} \mathrm{~S}_{5}$ according to the next formula.

$$
4 \mathrm{ROH}+\mathrm{P}_{2} \mathrm{~S}_{5} \longrightarrow 2 \stackrel{\mathrm{RO}}{\mathrm{RO}}>\mathrm{P}\left\langle/ \mathrm{SH}+\mathrm{SH}_{2}\right.
$$

Authors obtained these products by reacting at $65 \sim 85^{\circ} \mathrm{C}$ for $5 \sim 8 \mathrm{hrs}$. with best yield. The dispersion tests of inorganic pigments by Na-dialkyldithio-phosphate were carried out by sedimentograph.

The results were as follows. :

1) The rate of sedimentation were arranged as folloing order: $\mathrm{TiO}_{2}, \mathrm{SiO}_{2}$, caolin, $\mathrm{CaCO}_{3}$, $\mathrm{BaCO}_{3}, \mathrm{Al}_{2} \mathrm{O}_{3}, \mathrm{Zn} \mathrm{O}, \mathrm{Fe}_{2} \mathrm{O}_{3}$ increasingly.

2) The dispersabilities of caolin, $\mathrm{Fe}_{2} \mathrm{O}_{3}, \mathrm{BaCO}_{3}$ in aqueous medium were improved by addition of Na-dialkyldithiophosphate. Particularly, these dithiophosphoric acid salts having two straight long chain radicals as $\mathrm{R}$ were excellent dispersants. $\mathrm{SiO}_{2}, \mathrm{CaCO}_{3}, \mathrm{Al}_{2} \mathrm{O}_{3}, \mathrm{ZnO}$ were flocculated in water, while addition of entitled short branched chain compound produced good deflocculation.

3) Rutile and sand were affected little by addition of these additives.

4) Dispersion of light oil and anthracen lampblack were improved for the former especially, by addition of mixtures of $\mathrm{Zn}$-dialkyldithiophosphate to non aqueous medium when the content of upper dithiophosphoric acid $\mathrm{Zn}$ salts having two long chain alkyl radical as $\mathrm{R}$ was large.

* Sendamachi, Hiroshima-Shi, Japan.

** Mitsuyaminamidôri, Higashiyodogawa-ku Osaka, Japan. 


\section{ジアルキルジチオリン酸系分散剂の研究 ${ }^{\text {UDC }} 661.185: 547.26^{\prime} 118.5^{\prime 2} 221$ \\ 539.215 .08}

根来 健二**赤松 純雄**・北脇 英雄*

要

旨

アルコールとしてイソプロピルアルコール, n-ブタノール, ラウリルアルコール, ステアリルアルコ ールなどのアルコール類と五二硫化リンと反応させると次式により

$$
4 \mathrm{ROH}+\mathrm{P}_{2} \mathrm{~S}_{5} \rightarrow 2 \stackrel{\mathrm{RO}}{\mathrm{RO}}>\mathrm{P} \stackrel{\mathrm{S} H}{\mathrm{SH}}+\mathrm{SH}_{2}
$$

ジアルキルジチホスフェイトが得られる。この際の反応条件が従来明らかにされていないので検討し たところ原料のモル比は理論量, 反応温度は $65 \sim 85^{\circ} \mathrm{C}$, 反応時間は $5 \sim 8 \mathrm{hrs}$ の条件が最適であつた。 反応液に計算量の水酸化ナトリウム水溶液を加兄て正確に中和後, 減圧にて蒸発乾燥することによりナ トリウム塩を得た。

以上のソジゥムジアルキルジチオリン酸の浮遊選鉱剂としての適性を調べるため無機体質顔料 8 種類 を分散質として分散分析を行なった結果，

1）無添加のときの沈降.の順序は酸化チタン，シリカゲル，カオリン，炭酸カルシウム，炭酸バリウ ム, アルミナ, 亜鉛華, 酸化第一鉄（褐）の順で大体比重の順になる。

2） ジアルキルジチオリン酸トリウム塩の添加によりカオリン, $\mathrm{Fe}_{2} \mathrm{O}_{3}, \mathrm{BaCO}_{3}$ の分散性が改善せら れ，これらはまたジチオリン酸のアルキル鎖として分岐のない長鎖のものほど効果がよかった。一方か 党って凝集的に働く場合としては，シリカゲル， $\mathrm{CaCO}_{3}, \mathrm{Al}_{2} \mathrm{O}_{3}, \mathrm{ZnO}$ が女り，これは分岥のある短鎖 のものの方が分岐改善せられる。ケイ砂とか酸加チタンは，要まりチオリン酸塩の添加により分散の影 響を受けなかった。またジアルキルジチオリン酸の Zn 塩を製したのちカーボンブラックの油中分散を 検討した。その結果軽油招よびアンスラセンランプブラックはともにテオリン酸の Zn 塩の添加により 分散がよくなるが，前者は特に長鎖アルキル成分の含量の多い $\mathrm{Zn}$ 塩の方により分散がすぐれ，後者の アンスラセンランプブラックは適当な長さのものが分散結果がよかった。

\section{1. 緒言}

リンイオウ化合物を浮遊選鉱剤の捕集剤として用いる ためこれらの合成掠よびその性質などについて研究を行

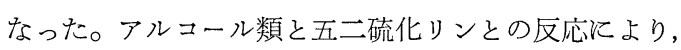
ジアルキルジチオホスフェートが得られる。

このジアルキルジチオホスフェートを各論で述べるよ 万に合成し，水溶性塩としてナトリウム塩を，物よび油 溶性塩として带鉛塩とし，それら単独またはアルキル鎖 の異なる各種を混合することによりその分散力（浮遊選 鉱能力）の差を見るため累積形沈降分析を行なうことに より諸種の知見を得た。

昭 39. 10. 5 受理

* 広島大学工学部 広島市千田町 3

** 旭染料整造所研究部 大阪市東淀川区三津屋南通
2. ジアルキルジチオリン酸の合成

\section{1 ジイソプロピルジチオリン酸の合成}

容量 $100 \mathrm{cc}$ の 4 つロフラスコに塩化カルシウム管を つけた還流冷却器, かきまぜ器, 温度計を取りつける。 イソプロピルアルコール (MW 60.9) $48 \mathrm{~g}$ を入れ, はげしいかくはん下に十分に微粉研した五二硫化りツ (MW 222.28) $44 \mathrm{~g}$ を少量ずつ内温が上昇しないように フラスコを冷しながら 3 分間で加兄る。しばらくかきま ぜた後恒温槽に入れ $50^{\circ} \mathrm{C}$ で反応を続ける。反応開始後 5 分, 15 分, 30 分, 1 時間, 2 時間, 4 時間, 6 時間 特よび 8 時間の各反応時間に特いて 4 つロフラスコ中よ り反応生成物を $5 \mathrm{ml}$ ずつ取り出し, 吸引口過し, 未反 応の五二硫化リンを除去後試験管に取りゴム栓をする。 この試料から正確に約 $0.3 \mathrm{~g}$ を取り $20 \mathrm{ml}$ のメチルア ルコールに溶かして容量 $200 \mathrm{ml}$ のビーカーに入れる。 これを水で希瀵して全体を $100 \mathrm{~m} l$ とし，これと $\mathrm{pH}$ メ

$\overline{16[4]}$ 
一ターのガラス電極をひたし，マグネテックスターラー でかきまぜながら，ビューレットから $1 / 10 \mathrm{~N}$ の水酸化 ナトリウムの $20 \%$ メチルアルコール溶液により中和滴定 する。ビューレットからの標準試薬溶液の滴下量と $\mathrm{pH}$ メーターの值とプロットして作った中和曲線から水酸化 ナトリウム溶液の当量点を求め, ジイソプロピルジチオ ホスフェートの生成率を算出した。同様にして $60^{\circ} \mathrm{C}$, $70^{\circ} \mathrm{C}, 85^{\circ} \mathrm{C}$ の各温度に拈いても上記の各反応時間に反応 生成物を取り出し $\mathrm{pH}$ 滴定を行なった。反応が進むにつ れて生成物の色の变化がみられ，淡紫色から暗褐紫色に 変わり,さらに進むと再び淡紫色になり，最終的には無 色透明の液体となる。各色に達するまでの所要時間を 表-1 に示す。

つぎに $\mathrm{pH}$ 滴定曲線から計算したジイソプロピルジチ オホスフェートの収率と反応時間牤よび温度との関係を 表-2 に示す。

表-1 変色所要 時間

\begin{tabular}{c|c|c|c|c}
\hline $\begin{array}{c}\text { 反応 } \\
\text { 温度 }\left({ }^{\circ} \mathrm{C}\right)\end{array}$ & $\begin{array}{c}\text { 淡 紫 } \\
(\mathrm{min})\end{array}$ & $\begin{array}{c}\text { 暗 } \\
(\mathrm{hrs})\end{array}$ & $\begin{array}{c}\text { 紫 } \\
(\mathrm{hrs})\end{array}$ & $\begin{array}{c}\text { 無 } \\
(\mathrm{hrs})\end{array}$ \\
\hline 50 & 15 & & & \\
60 & 15 & 4 & 8 & \\
70 & 5 & 4 & 6 & 8 \\
85 & 5 & 0.5 & 1 & 2 \\
\hline
\end{tabular}

表-2 反応温度および時間と収率（\%)

\begin{tabular}{c|r|r|r|r|r|r|r|r}
\hline $\begin{array}{c}\text { 反店 } \\
\text { 反応 } \\
\text { 温度(C) }\end{array}$ & 5 分 & 15 分 & 30 分 & $\begin{array}{l}1 \text { 時 } \\
\text { 間 }\end{array}$ & $\begin{array}{c}2 \text { 時 } \\
\text { 間 }\end{array}$ & $\begin{array}{c}4 \text { 時 } \\
\text { 間 }\end{array}$ & $\begin{array}{l}6 \text { 時 } \\
\text { 間 }\end{array}$ & $\begin{array}{l}8 \text { 時 } \\
\text { 間 }\end{array}$ \\
\hline 50 & 62.3 & 72.8 & 78.4 & 81.6 & 88.7 & - & 90.9 & - \\
60 & 65.1 & 95.5 & 81.6 & 86.0 & 87.5 & 85.1 & 89.9 & 93.1 \\
70 & $* 69.3$ & $* 72.4$ & 79.2 & 83.8 & 88.0 & 89.3 & 91.1 & 88.7 \\
85 & 83.6 & 85.4 & 87.9 & 93.1 & 94.5 & 93.0 & 86.9 & 83.6 \\
\hline
\end{tabular}

注) * $\mathrm{pH}$ 滴定曲線を書くと時によっては二段曲線と なることがある。イソプロピルアルコールの場 合， $70^{\circ} \mathrm{C}$ の反応生成に掠いて 5 分と 15 分の二つ の場合に二段曲線となっているが段が小さいので そのまま平均的な場所を選んで $\mathrm{pH}$ 滴定曲線の中 点とした。

\section{2 ジ-n-ブチルジチオリン酸の合成}

$\mathrm{n}$-ブチルアルコール（分子量 73） $55.6 \mathrm{~g}$, 五二硫化り ン $41.7^{\circ} \mathrm{C}$, 反応温度は $60^{\circ} \mathrm{C}, 85^{\circ} \mathrm{C}$ 扤よび $98^{\circ} \mathrm{C}$ の三つ である。他は同一操作である。ただし $\mathrm{pH}$ 滴定の場合試 料溶液沶よび $\mathrm{N} / 10$ 水酸化ナトリウム溶液ともに $30 \%$ メ タノール溶液とした。 $n$-ブチルアルコールと五二硫化 リンの反応が進み，生成率 $90 \%$ 近くになると生成物が 20\%アルコール溶液には溶けにくくなるからである。
表-3 変色所要 時間

\begin{tabular}{c|c|c|c|c}
\hline $\begin{array}{c}\text { 反応 } \\
\text { 温度 }\left({ }^{\circ} \mathrm{C}\right)\end{array}$ & $\begin{array}{c}\text { 色 } \\
(\mathrm{min})\end{array}$ & $\begin{array}{c}\text { 暗 } \\
(\mathrm{hrs})\end{array}$ & $\begin{array}{c}\text { 紫 } \\
(\mathrm{hrs})\end{array}$ & $\begin{array}{c}\text { 無 } \\
(\mathrm{hrs})\end{array}$ \\
\hline 60 & 60 & 8 & & \\
85 & 15 & 1 & 4 & 6 \\
98 & 5 & 1 & 2 & 4 \\
\hline
\end{tabular}

表-4 反応温度拉よび時間と収率（\%)

\begin{tabular}{c|c|c|c|c|c|c|c|c|c}
\hline $\begin{array}{c}\text { 反店間 } \\
\text { 反应 }\end{array}$ & 5 分 & 15 分 & 30 分 & $\begin{array}{c}1 \text { 時 } \\
\text { 間 }\end{array}$ & $\begin{array}{c}2 \text { 時 } \\
\text { 間 }\end{array}$ & $\begin{array}{c}4 \text { 時 } \\
\text { 間 }\end{array}$ & $\begin{array}{c}6 \text { 時 } \\
\text { 間 }\end{array}$ & $\begin{array}{c}8 \text { 時 } \\
\text { 間 }\end{array}$ \\
\hline 60 & 70.1 & 75.5 & 80.1 & 81.5 & 84.7 & 85.1 & 85.4 & 87.3 \\
85 & 81.6 & 82.9 & 85.7 & 87.5 & 93.9 & 89.9 & 87.7 & 79.9 \\
98 & 81.5 & 82.7 & 85.4 & 86.8 & 87.5 & 85.4 & 80.6 & 77.1 \\
\hline
\end{tabular}

つぎに反応温度による着色変化時間を表-3に示す。

表-4 に pH 滴定曲線から計算したジーnーブチルジチオ ホスフェートの収率と反応時間和よび温度の関係を示: 与。

\section{3 ジラウリルジチオリン酸の合成}

ラウリルアルコール（分子量 186.34）46.6 g, 五二硫 化リン $13.9 \mathrm{~g}$, 反応温度は $85^{\circ} \mathrm{C}, 98^{\circ} \mathrm{C}$ 洛よび $150^{\circ} \mathrm{C}$ の 3 つである。( $150^{\circ} \mathrm{C}$ は油浴を使用) $\mathrm{pH}$ 滴定は，ラウ リルアルコールと五二硫化リンの反応生成物はメチルア ルコールには溶けないのでイソプロピルアルコールを使 う。試料約 $0.3 \mathrm{~g}$ を正確に計りこれを $40 \mathrm{cc}$ のイソプロ ピルアルコールに溶かし水で希釈して $100 \mathrm{cc}$ とする。 標準試薬の $1 / 10 \mathrm{~N}$ 水酸化ナトリウム溶液も $40 \%$ イソ プロピル溶液とする。他の条件は同一とする。変色所要 時間を表-5 に示す。

表-6 に pH 滴定曲線から計算したジラウリルジチオ 表-5 変色所 要 時 間

\begin{tabular}{c|c|c|c|c}
\hline \multicolumn{1}{|c|}{ 反店 } & $\begin{array}{c}\text { 淡 紫 } \\
(\mathrm{min})\end{array}$ & $\begin{array}{c}\text { 暗 紫 } \\
(\mathrm{hrs})\end{array}$ & $\begin{array}{c}\text { 淡 紫 } \\
(\mathrm{hrs})\end{array}$ & $\begin{array}{c}\text { 無 色 } \\
(\mathrm{hrs})\end{array}$ \\
\hline $\begin{array}{r}\left.{ }^{\circ} \mathrm{C}\right) \\
85\end{array}$ & 60 & 4 & 6 & 8 \\
98 & 30 & 2 & 4 & 6 \\
150 & 5 & 0.5 & $2 / 3$ & 1 \\
\hline
\end{tabular}

表-6 反応温度および時間と収率（\%)

\begin{tabular}{|c|c|c|c|c|c|c|c|c|}
\hline $\begin{array}{c}\text { 反底 } \\
\text { 時間 } \\
\text { 反底 } \\
\text { 温度 (C) }\end{array}$ & 5 分 & 15分 & 30 分 & $\begin{array}{l}1 \text { 時 } \\
\text { 間 }\end{array}$ & $\begin{array}{c}2 \text { 時 } \\
\text { 間 }\end{array}$ & $\begin{array}{l}4 \text { 時 } \\
\text { 間 }\end{array}$ & $\begin{array}{l}6 \text { 時 } \\
\text { 間 }\end{array}$ & $\begin{array}{l}8 \text { 時 } \\
\text { 間 }\end{array}$ \\
\hline 85 & 41.9 & 57.8 & 67.8 & 79.8 & 85.0 & 89.0 & 88.5 & 86.7 \\
\hline 98 & 45.3 & 60.8 & 75.4 & 83.8 & 87.5 & 83.8 & $*_{1}$ & $* 2$ \\
\hline 150 & 79.9 & 87.5 & 83.0 & 62.1 & 6.9 & - & - & - \\
\hline \multicolumn{2}{|c|}{ *1 1 段目 } & \multirow{2}{*}{\multicolumn{3}{|c|}{$\begin{array}{l}85.2 \% \\
88.5 \%\end{array}$}} & \multirow{2}{*}{\multicolumn{3}{|c|}{$\begin{array}{l}107.5 \% \\
126.0 \%\end{array}$}} & \\
\hline$* 2$ & 段目 & & & & & & & \\
\hline
\end{tabular}


ホスフェートの収率と反応温度和よび時間の関係を示 す。 $\mathrm{pH}$ 滴定の結果 $98^{\circ} \mathrm{C}$ の反応の場合，6時間敌よび 8 時間後の曲線は，2段曲線となりどちらも収率の值と して取るのは無理のようで嵓る。これを表中の*1 叔よ び*2で表外に示すこと沉する。また， $150^{\circ} \mathrm{C}$ の反応沉 特いては 4 時間後に弫とんど全部がジラウリルジチオホ スフェート以外の物質になっているらしく $\mathrm{pH}$ 滴定の值 が出なかった。

\section{4 ジステアリルジチオリン酸の合成}

フラスコにステアリルアルコール（分子量 270.5) $45.1 \mathrm{~g}$ を入れ，これを約 $60^{\circ} \mathrm{C}$ に温めて液体とする。こ れに微粉砕した五二硫化りン $9.2 \mathrm{~g}$ 劣少量ずつ1分間で 加光, 加え終ってから恒温槽に入れ反応を行なう。反応 温度は $85^{\circ} \mathrm{C}, 98^{\circ} \mathrm{C}$ 扣よび $120^{\circ} \mathrm{C}$ の 3 つである。同様サ ムプリングは同様であるが生成物がかたまりやすいので, 各時間でフラスコから反応生成物 $5 \mathrm{ml}$ ずつ取り出し保 温漏斗ですばやく吸引口過し, その一部を正確に計り 取り, $\mathrm{pH}$ 滴定を行なう。ステアリルアルコールと五二 硫化リンの反応物は常温で固体であるから約 $40^{\circ} \mathrm{C}$ に熱 し，これを温イソプロピル溶液（約 $40^{\circ} \mathrm{C}$ ) $50 \mathrm{cc}$ に溶か 乙，これを温水で希釈して $100 \mathrm{~m} l$ とし測定を行なう。 この場合も反応生成物は時間の変化につれて色変化す る。しかし反応生成物は常温では口ウ状物質であるので (1)，（2），（3）の時ほど著しい色の変化はみられな い。表-7 に温度での色の变化を示す。

反応温度 $98^{\circ} \mathrm{C}$ のとの反応で, 反応開始後 8 時間目 飞は海綿状の沈殿物が反応容器内に生成し, 液の粘度が 高くなり，5cc を取り出すサンプリングの操作の後の口 過がしにくくなった。 $\mathrm{pH}$ 浻定曲線が反応温度 $98^{\circ} \mathrm{C}$, 時 間は 6 時間後と 8 時間後の時 2 段曲線となる。その平均 的な場所を選んでその中点とし, 収率の值としてとっ

表-7 变色所要 時間

\begin{tabular}{r|c|c|c}
\hline $\begin{array}{c}\text { 反応 } \\
\text { 温度 }\left({ }^{\circ} \mathrm{C}\right)\end{array}$ & $\begin{array}{c}\text { クリ-公色 } \\
(\mathrm{min})\end{array}$ & $\begin{array}{c}\text { 暗 ク } \\
-\begin{array}{c}\text { リ } \\
(\mathrm{hrs})\end{array}\end{array}$ & $\begin{array}{c}\text { クリーム色 } \\
(\mathrm{hrs})\end{array}$ \\
\hline 85 & 60 & 4 & 8 \\
98 & 30 & 1 & 3 \\
120 & 5 & 0.5 & 2 \\
\hline
\end{tabular}

表-8 反応温度および時間と収率（\%)

\begin{tabular}{r|r|r|r|r|r|r|r|r}
\hline $\begin{array}{c}\text { 反応 } \\
\text { 反時間 }\end{array}$ & 5 分 & 15 分 & 30 分 & $\begin{array}{c}1 \text { 時 } \\
\text { 間 }\end{array}$ & $\begin{array}{c}2 \text { 時 } \\
\text { 間 }\end{array}$ & $\begin{array}{c}4 \text { 時 } \\
\text { 間 }\end{array}$ & $\begin{array}{c}6 \text { 時 } \\
\text { 間 }\end{array}$ & $\begin{array}{l}8 \text { 時 } \\
\text { 間 }\end{array}$ \\
\hline 85 & 27.7 & 52.6 & 59.2 & 64.7 & 72.4 & 80.8 & 89.7 & 85.5 \\
98 & 42.0 & 55.7 & 60.5 & 75.0 & 82.4 & 85.8 & 96.6 & 97.8 \\
120 & 57.6 & 76.2 & 80.2 & 84.5 & 89.1 & 82.4 & 69.0 & 63.0 \\
\hline
\end{tabular}

た。表-8に pH 滴定曲線から計算したジステアリルジ チオホスフェートの収率と反応温度和よび時間の関係さ 示す。

\section{3. ジアルキルジチオリン酸ナトリウム 塩の合成}

\section{1 ジイソプロピルジチオリン酸ナトリウム}

生成率 $82.1 \%$ のジイソプロピルジチオリン酸 $10 \mathrm{~g}$ 学 $50 \mathrm{ml}$ のメチルアルコールに溶かし, 水学加えて全体 を $100 \mathrm{ml}$ とする。これに計算量の水酸化ナトリウム $1.53 \mathrm{~g}$ を50\%メチルアルコール溶液に溶かしたものを 加光て中和する。 $45^{\circ} \mathrm{C}, 30 \mathrm{mmHg}$ で 36 時間減圧乾喿 を行ない，アルコール蛒よび氷を除去した。ナトリウム 塩の収量 $10.5 \mathrm{~g}$ 。

\section{2 ジーn-ブチルジチオリン酸ナトリウム}

反応温度 $60^{\circ} \mathrm{C}$, 反応時間 9 時間で $n$-ブチルアルコー ルと五二硫化リンを反応させ，生成率 $92.8 \%$ でジーnブチルジチオホスフェートを得た。この $10 \mathrm{~g}$ を取り, $50 \mathrm{cc}$ のメチルアルコールに溶かし水で希釈して $100 \mathrm{cc}$ とし, これ計算量の水酸化ナトリウム $1.4 \mathrm{~g}$ を $50 \%$ メ チルアルコールに溶かした溶液を加えて中和する。 $45^{\circ} \mathrm{C}$, $30 \mathrm{mmHg}$ の減圧下で 36 時間乾燥を行ないアルコール 招よび水を除去した。ナトリウム塩の収量 $10.1 \mathrm{~g}$ 。

\section{3 ジラウリルジチオリン酸ナトリウム}

反応温度 $98^{\circ} \mathrm{C}$, 反応時間 2 時間でラウリルアルコー ルと五二硫化りンを作用させ，生成率 $82.0 \%$ でジラウ リルジチオホスフェートを得た。このジチオホスフェー ト $10 \mathrm{~g}$ を取りイソプロピルアルコール50 cc に溶かし, これを水で希秎して $100 \mathrm{cc}$ とする。計算量の水酸化ナ トリウム $0.6 \mathrm{~g}$ 起水 $10 \mathrm{cc}$ とイソプロピルアルコール $40 \mathrm{ml}$ との混液に溶かしたものを上記のジチオホスフェ 一トのアルコール溶液にかきまぜながら加光て中和し, ナトリウム塩にする。 $45^{\circ} \mathrm{C}, 30 \mathrm{mmHg}, 36$ 時間で減圧 乾燥し，水就よびアルコールを除去する。ナトリウム塩 の収量 $9.6 \mathrm{~g}$ 。

\section{4. ジアルキルジチオリン酸亜鉛塩の合成}

\section{1 ジラウリルジチオリン酸亜鉛}

ジラウリルジチオリン酸（生成率 $82.0 \%$ ）の $10 \mathrm{~g}$ とりイソプロピルアルコール50ccに溶かし水で希釈し て全量 $100 \mathrm{cc}$ とする。一方計算量の水酸化ナトリウム $0.6 \mathrm{~g}$ を水 $10 \mathrm{cc}$ に溶かし, これにイソプロピルアルコ ール $40 \mathrm{cc}$ を加えた溶液を作り，これを上記のジチオリ ン酸のイソプロピルアルコール溶液にかきまぜながら加 えて行き, $\mathrm{pH}$ 試験紙 $\mathrm{BTB}$ と $\mathrm{CR}$ 使って $\mathrm{pH} 7.8$ と 
乙30 分間マグネテックスターラーでかきまぜ後，これ 化計算量の塩化亜鉛 $1.9 \mathrm{~g}$ 水 $2 \mathrm{cc}$ 儿溶かした溶液を 除々飞滴下寸る。滴下終了後な沏約 30 分活どかきまぜ る。この亜鉛塩溶液に $100 \mathrm{cc}$ のリグロインを加え分液 漏斗に移し, 水で良く洗5。リグロインで抽出された部 分を分離し，リグロインを $30^{\circ} \mathrm{C} ， 100 \mathrm{mmHg} ， 24$ 時間 で減圧除去する。亜鉛塩の収量 $8.5 \mathrm{~g}$ 。

\section{2 ジステアリルジチオリン酸重鉛}

反応温度 $98^{\circ} \mathrm{C}$, 反応時間 5 時間で得た生成率 $85.8 \%$ のジステアリルジチオリン酸の $10 \mathrm{~g}$ を $50^{\circ} \mathrm{C}$ に温的て 液体とし，これКイソプロピルアルコール $40 \mathrm{cc}$ と水 $40 \mathrm{cc}$ を加えて溶かし，さらにこの中に粒状の水酸化ナ トリウム $0.54 \mathrm{~g}$ を入て溶かす。 $\mathrm{pH}$ 試験紙で調べる

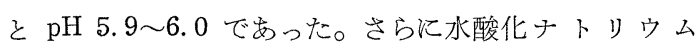
$0.0865 \mathrm{~g}$ を加光て B. T.B ; C.R. て pH 7.6 とした。 $.50^{\circ} \mathrm{C}$ でこのナトリウム塩溶液什計算量の塩化亜鉛 0.88 $\mathrm{g}$, ついで追加した水酸化ナトリウムの量に相当する $0.1409 \mathrm{~g}$ の計約 $1.02 \mathrm{~g}$ を水 $2 \mathrm{cc}$ に溶かした溶液を滴 下する。な技 30 分ほどかきまぜた後約 $50^{\circ} \mathrm{C}$ の温りグ ロインでもって抽出を行なら。リグロインの量は他の場 合と同じく $100 \mathrm{cc}$ である。 $30^{\circ} \mathrm{C}, 10 \mathrm{mmHg}, 24$ 時間で 減压にしリグロインを除去して, 亜鉛の塩を得る。亜鉛 塩の収量 $10 \mathrm{~g}$ 。他の反応条件のものも合わ世て表-9 に まとめた。

\section{5. ジアルキルジチオホスフェートによ る分散の測定について}

表-9 ジステアリルジチオホスフェートの亜鉛塩製造の条件

\begin{tabular}{|c|c|c|c|c|c|c|c|}
\hline & \multirow{2}{*}{ 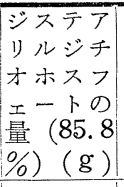 } & \multirow{2}{*}{$\begin{array}{c}\text { 反応液 } \\
\text { の温度 } \\
\left({ }^{\circ} \mathrm{C}\right)\end{array}$} & \multicolumn{2}{|c|}{$\begin{array}{l}\text { ジチオホスフ } \\
\text { エートの溶剂 }\end{array}$} & \multirow{2}{*}{$\begin{array}{c}\text { ナトリウム } \\
\text { 塩を作るた } \\
\text { のの水酸化 } \\
\text { ナトリウム } \\
(\mathrm{g})\end{array}$} & \multicolumn{2}{|c|}{$\begin{array}{l}\text { 水酸化ナトリ } \\
\text { ウムの溶剂 }\end{array}$} \\
\hline & & & $\begin{array}{c}\text { イソプロ } \\
\text { ピルアル } \\
=\text {-ル } \\
(\mathrm{m} l)\end{array}$ & $\begin{array}{l}\text { 水 } \\
(\mathrm{m} l)\end{array}$ & & 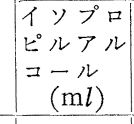 & $\begin{array}{l}\text { 水 } \\
(\mathrm{m} l)\end{array}$ \\
\hline a & 10 & 常 温 & 50 & 50 & 0.54 & 40 & 2 \\
\hline b & 10 & $40 \sim 50$ & 100 & 20 & $0.54+0.09$ & 10 & 2 \\
\hline c & 10 & 50 & 50 & 50 & $0.54+0.09$ & なし & なし \\
\hline \multirow[t]{2}{*}{ d } & 10 & 50 & 40 & 40 & $0.54+0.0865$ & なし & なし \\
\hline & $\begin{array}{l}\text { ナトリウ } \\
\text { ム塩を作 } \\
\text { るときの } \\
\text { pH }\end{array}$ & $\begin{array}{l}\text { 亜鉛 } \\
\text { るた } \\
\text { 化亜 } \\
\end{array}$ & 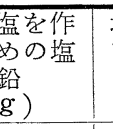 & $\begin{array}{c}\text { 塩化垔鉛 } \\
\text { を溶解す } \\
\text { る水の量 } \\
(\mathrm{ml} l)\end{array}$ & 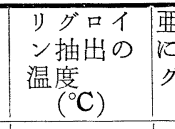 & $\begin{array}{l}\text { 垔鉛塩抽出 } \\
\text { に用たたり } \\
\text { グロイソ } \\
(\mathrm{m} l)\end{array}$ & $\begin{array}{c}\text { 亜鉛塩 } \\
\text { 收量 } \\
(\mathrm{g})\end{array}$ \\
\hline a & - & & 88 & 2 & 常 温 & 100 & 9.8 \\
\hline b & 7.6 & & 88 & 1 & 常 温 & 100 & 8.5 \\
\hline $\mathrm{c}$ & 7.6 & & 88 & 2 & 常 温 & 100 & 6.4 \\
\hline $\mathrm{d}$ & 7.6 & $0.88+$ & -0.1303 & 2 & $50^{\circ} \mathrm{C}$ & 100 & 10 \\
\hline
\end{tabular}

注） b， d が沈殿できず， a， c は沈殿ができた。上表から沈殿が できず，かつ Zn 塩の収量がよかったのが実験例に示したdである。

\section{1 ナトリウム塩による水中分散}

ジイソプロピルジチオリン酸, ジーnーブチルジチオ リン酸怙よびジラウリルジチオリン酸のナトリウム塩の 表-10 亿示すような配合割合（分散剂濃度 $0.05 \%$ ）で分 散能力の測定を, 水渡, 荒川式自動粒度測定器 SA II 形 で行なった。分散質としてアルミナ（和光*1），酸化再 鉛 (和光), 二酸化チタン(和光), 岸酸バリウム(和光), 酸化第二鉄 (関東*2), シリカゲル (関東), 炭酸カルシ ウム (和光), カホリン (関東), 軽油ランプブラック （浪速硝煙*3），アンスラセンランプブラック（浪速硝煙） を用いた。

表-10 の各数字は重量比による配合割合を示す。表一 10 のような分散剤の配合割合で分散剤をまぜて, 測定 用円筒容器に入れ, 水起加元て $400 \mathrm{cc}$ と, 各分散剂 表-10 分散剂の配 合 割 合

\begin{tabular}{|c|c|c|c|c|c|c|c|}
\hline 番 & 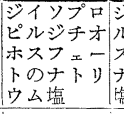 & 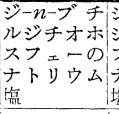 & $\begin{array}{l}\text { ジラウリル } \\
\text { ジチオホス } \\
\text { フェートの } \\
\text { ナトリウム } \\
\text { 塩 }\end{array}$ & 番 & $\begin{array}{l}\text { ジイソプロ } \\
\text { ピルジチオ } \\
\text { ホスフェニ } \\
\text { トのナトリ } \\
\text { ウム塩 }\end{array}$ & 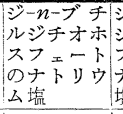 & 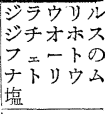 \\
\hline 1 & - & - & - & 9 & 17 & 1 & 2 \\
\hline 2 & 10 & - & - & 10 & 13 & 5 & 2 \\
\hline 3 & - & 10 & - & 11 & 9 & 9 & 2 \\
\hline 4 & 9 & 1 & - & 12 & 5 & 13 & 2 \\
\hline 5 & 7 & 3 & - & 13 & 1 & 17 & 2 \\
\hline 6 & 5 & 5 & - & 14 & 9 & & 1 \\
\hline 7 & 3 & 7 & - & 15 & & 9 & 1 \\
\hline 8 & 1 & 9 & - & & & & \\
\hline
\end{tabular}

濃度 $0.05 \%$ の水溶液として試験した。 各分散質のそれぞれ $5 \mathrm{~g}$ を上皿テンビン ではかり，測定用円筒容器に入れ 1 分間 ガラス棒でかきまぜて均一に分散させ， ただちに自動粒度測定器にしかけて沈降 曲線をかかせた。

な特，以後表-10 亿従って配合割合番 号で各分散剂配合を代さ表せる。

\section{1 .1 アルミナの分散}

測定時液温 $33.8 \sim 34.5^{\circ} \mathrm{C}$ 。

ぞの配合割合の時も，水のみによる分 散より分散性が悪くなっている。特にジ ラウリルジチォホスフェートの塩を混合 すると凝集が起こり，分散性低下の傾向 は著しい。分散はいずれも悪いがよいも のからならべると (1), (5), (4); (3), (9),

注 $* 1$ 和光純薬 $\mathrm{K} . \mathrm{K}$. 製 $* 2$ 関東化学 $\mathrm{K} \cdot \mathrm{K} \cdot$ 製 *3 浪速硝煙製 
(14)，(8)，(12)，(15)，(6)，(7)，(11)，(10，(13)，(12)の順に分散が 余計に悪くなった。

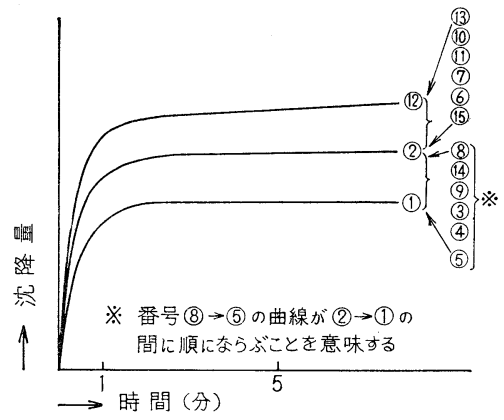

図-1 アルミナの分散曲線

\section{1 .2 酸化亜鉛の分散}

湘定時液温 $33 \sim 34^{\circ} \mathrm{C}$ 。

図-2 より (2)〜15)のどの配合割合のときも，水のみに よる分散の場合上り分散性が悪くなっている。特にジラ ウリルジチオホスフェートを混合すると凝集性が高まり, 分散性が低下するのはアルミナの場合と同様である。(1), (3), (6), (19), (7), (2), (5), (8)=(13), (4), (9)=(10)=(11)=(15), (9), (1010，(11)，(14)，(15)の順に後注ど凝集傾向が大である。 初期に凝集的に沈降。これらの結果を図-2 と示す。

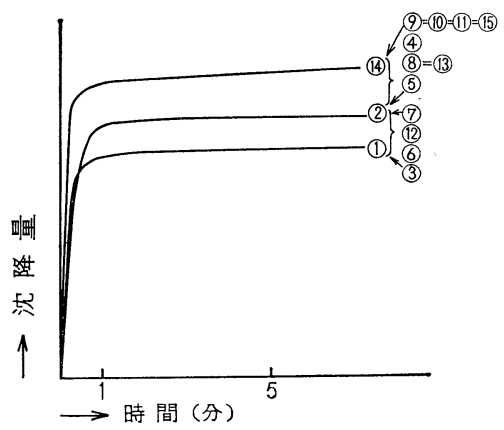

図-2＼cjkstart酸化亚鉛の分散曲線

\section{1 .3 二酸化チタンの分散}

測定時液温 $33 \sim 34^{\circ} \mathrm{C}_{\text {。 }}$

水のみによる分散（ブランクテスト）自体分散性が大 であり, 分散剂の混合によってもその傾向は変わらず, 比較するのがかなりむずかしい。(4)，(11)（12)，(13はブラ ンクテストと同じ曲線を描く。(10のみは全く沈降しない のでかなり分散効果はある。またその他のはブランクテ ストよりは少々分散性が悪いが，凝集性はない。比較す ることはいささかむずかしいので分散順位はつけない。 図-3に結果を示す。

\section{1 .4 炭酸バリウムの分散} 測定時液温 $33.2 \sim 34.0^{\circ} \mathrm{C}$

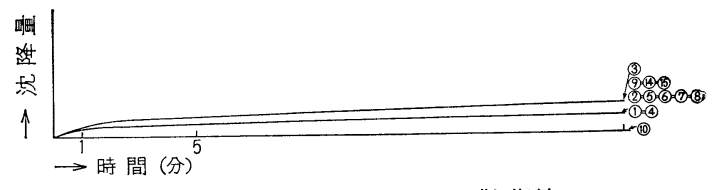

図-3 二酸化チタンの分散曲線

分散剤の配合割合番号でのジラウリルチオホスフェー トのナトリウム塩を配合していない場合は水のみによる 分散すなわちブランクテストの場合より分散性は少しよ くなっている。(9)〜15)のようにジラウリルジチオホスフ ェートのナトリウム塩を混合すると凝集性があらわれ分゙ 散性は低下する。分散のよいものからならべると(8)，(3)， (5)=(6), (4), (7), (13), (2), (14), (111), (12), (1), (15), (10), (9) の順であった。(9), (10), (11), (14), (15)は初期に凝集傾向が. あった。これらの結果を図-4に示す。

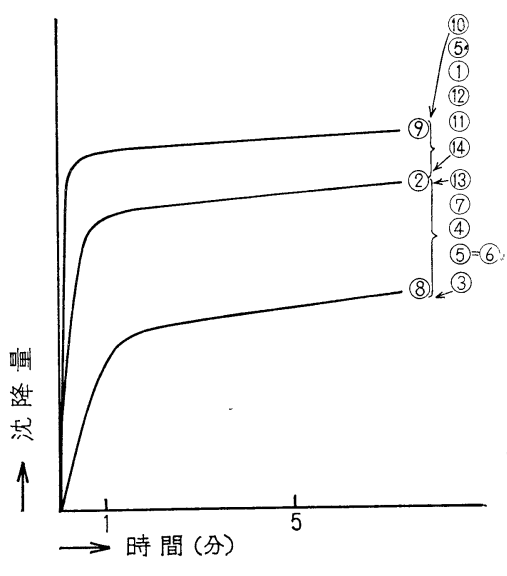

図-4 炭酸バリウムの分散曲線

\section{1 .5 酸化第二鉄の分散}

温定時液温 $32.5 \sim 33.5^{\circ} \mathrm{C}$ 。

一般に添加により分散性がよくなる。ジラウリルジチ オホスフェートのナトリウム塩の混合により分散性が堌

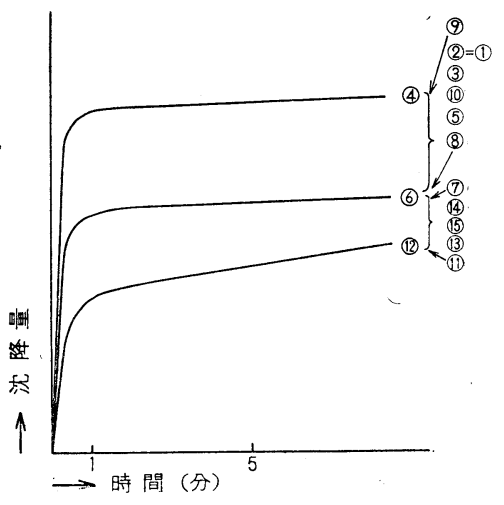

図-5 酸化第二鉄の分散曲線: 
加する。 (12)，(11)，(13)，(15)，(14)，(7)，(6)，(8), (5), (10), (3), (2)=(1)，(9)，(4)分散良 $\rightarrow$ 悪，以下これに準ずの順であっ た。(4)は初期の沈降が激しい。これらの結果を図-5 に 示した。

\section{1 .6 シリカダルの分散}

測定時液温 $32.5 \sim 32.7^{\circ} \mathrm{C}$ 。

いずれの配合割合に执いてもブランクテストより分散 性が悪くなっている。また，ジラウリルジチオホスフェ 一トのナトリウム塩の添加により変化がないのはシリカ ゲルの場合のみである。(3)=(6)=(1), (8), (9), (7), (9)= (10)= (11)= (12)=(13)= (14)，(15)，(4)の順であった。(4)の分散は 特に悪かった。これらの結果を図-6に示す。

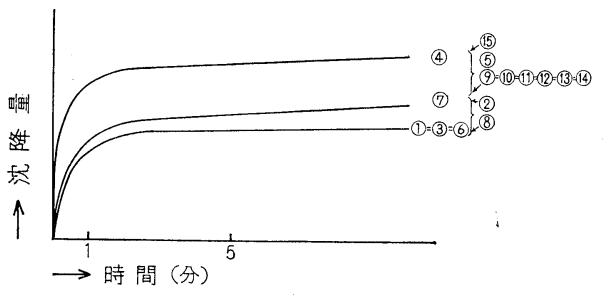

図-6 シリカガルの分散曲線

\section{1 .7 炭酸カルシウムの分散}

測定時液温 $32.0 \sim 32.2^{\circ} \mathrm{C}$ 。

分散剤添加により水だけとよる分散より悪くなる。(9) 〜15のようにジラウリルジチオリン酸のナトリウム塩を 配合すると凝集を起こし，初期にほとんどの炭酸カルシ ウムが沈降してしま5。(1)，(2)，(4)=(6)，(3)，(5)，(8)， (7), (12)=(13)= (14)=(15), (9)=(11)=(11)の順であった。(12)、(11), (14)，(15)，(9)、(10)、(11) 初期㠜集して沈降。これらの結 果を図-7 に示した。

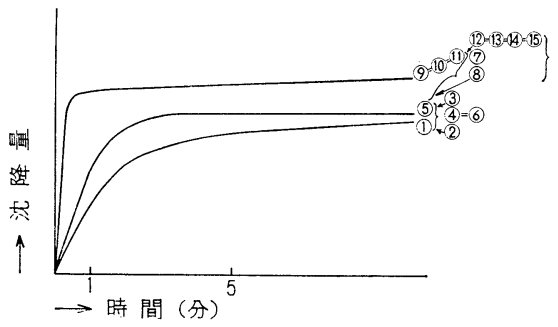

図-7 炭酸カルシウムの分散曲線

\section{1 .8 カオリンの分散}

\section{測定時液温 $29.2 \sim 29.7^{\circ} \mathrm{C}$ 。}

カオリンの分散比いては今までには全くみられなか ったすぐれた結果を示した。分散剂配合割合番号の(2)， (4)では測定開始後 5 分で, カオリンのほとんどが沈降し， ブランクテストの分散曲線と一致するが， 3 分後位まで はかなりの分散性をあらわす。また(3)，(5)招よび6は最
初の 5 分間位はかなりの分散性を示すが，10１5 分後汇 はだいたいブランクテストの分散曲線と一致する。これ に反して(9)，(10)特よび(144初めのうち1分間位はブラン クテストと同程度の分散性しか示さないが，2 分以後の 分散がよく, 10 分後において分散度を比較すると，たと えば(10)の場合はブランクテストの $2 / 3$ 程度の沈降量で女 る。つぎに(7)，(8)の場合をみると，(6)よりさらに分散性 がよく, 10 分後に沈降量がブランクテストの場合に比 べて $1 / 2$ 程度である。(11)，(12，(13)扔よび15に拈いては， 分散性はさらによく, 10 分後にブランクテストの沈降量 と比較し，その $1 / 3$ 程度しか沈降していない。

表-11 カオリン分散順位

\begin{tabular}{|c|c|c|c|}
\hline \multirow{2}{*}{$\begin{array}{l}\text { 配合 } \\
\text { 合番 } \\
\text { 割号 }\end{array}$} & \multicolumn{2}{|c|}{ 分 散順 位 } & \multirow{2}{*}{ 備 } \\
\hline & $\begin{array}{l}\text { はじめの } \\
5 \text { 分 間 }\end{array}$ & 5 分以後 & \\
\hline (1) & 13 & 15 & \\
\hline (2) & 11 & 14 & $\begin{array}{l}\text { はじめの } 2 \sim 3 \text { 分閒は少し分 } \\
\text { 散性がある }\end{array}$ \\
\hline (3) & 9 & 9 & $\begin{array}{l}\text { はじめの } 5 \text { 分位はかなりの分 } \\
\text { 散性がある }\end{array}$ \\
\hline (4) & 10 & 13 & $\begin{array}{l}\text { はじめの } 2 \sim 3 \text { 分間は少し分 } \\
\text { 散性がある }\end{array}$ \\
\hline$(5)$ & 8 & 8 & $\begin{array}{l}\text { はじめの } 5 \text { 分位はかなりの分 } \\
\text { 散性がある }\end{array}$ \\
\hline (6) & 7 & 7 & 同 上 \\
\hline ( 7 ) & 5 & 5 & かなりすぐれた分散性を示す \\
\hline ( 8 ) & 6 & 6 & 同 上 \\
\hline (9) & 14 & 11 & $\begin{array}{l}\text { はじめの } 1 \text { 分間位は良く沈降 } \\
\text { し, 後分散性よし }\end{array}$ \\
\hline (10) & 12 & 10 & 同 上 \\
\hline (11) & 3 & 3 & 非常にすぐれた分散性を示す \\
\hline$(12)$ & 2 & 2 & 同 上 \\
\hline (13) & 1 & 1 & 同 上 \\
\hline (14) & 15 & 12 & $\begin{array}{l}\text { はじめの } 1 \text { 分間位は沈降し, } \\
\text { その後分散性よし }\end{array}$ \\
\hline (15) & 4 & 4 & 非常にすぐれた分散性を示す \\
\hline
\end{tabular}

これらの結果を図-8 に示した。

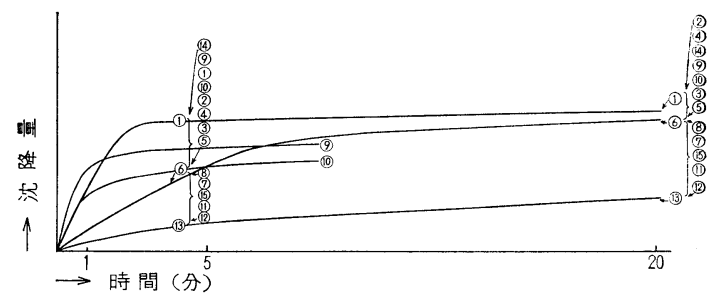

図-8 カオリンの分散曲線

\section{2 亜鉛塩による油中分散}

先に 4. (4.1.，4.2.) で述べたようにして作ったジラ 
ウリルジチオホスフェート拈よびジステアリルジチオホ スフェートの亜鉛塩を分散剤にし，リグロイン分散媒中 で軽油原料ランプブラック，アンスラセン原料ランプブ ラックの分散を測定した。

分散質のランプブラック $5 \mathrm{~g}$ をリグロイン $300 \mathrm{ml}$ に 入れて測定する。な特分散剂の亜鉛塩の濃度は $0.05 \%$ とした。測定器は水中分散の時と同様に自動粒度測定器 を使用した。ギアの回転時間は 30 分とする。表-12 に 分散剂の配合割合を示した。図中の番号は分散剂の配合 割合番号である。

表-12 分散剤の配合割合

\begin{tabular}{|c|c|c|}
\hline 番 号 & $\begin{array}{l}\text { ジラウリルジチオホ } \\
\text { スフェートの Zn 塩 }\end{array}$ & $\begin{array}{l}\text { ジステアリルジチオホ } \\
\text { スフェートの Zn 塩 }\end{array}$ \\
\hline 1 & 一 & - \\
\hline 2 & 10 & - \\
\hline 3 & 8 & 2 \\
\hline 4 & 6 & 4 \\
\hline 5 & 4 & 6 \\
\hline 6 & 2 & 8 \\
\hline 7 & - & 10 \\
\hline
\end{tabular}

5.2 .1 軽油原料ランプブラックのリグロイン中への 分散

測定時液温 $22.5^{\circ} \mathrm{C}$ 。

(7), (6)，(5)，(4)，(3)，(2)，(1)の順であり，一般に分散 剂添加により分散がよくなり，特にジステアリルジチオ リン酸の $\mathrm{Zn}$ 塩の含量が多くなるほど分散がよくなる傾 向であった。これらの結果を図-9に示した。

5.2 .2 アンスラセン原料ランプブラックのリグロイ ン中の分散

測定時液温 $19.8 \sim 20.0^{\circ} \mathrm{C}_{\text {。 }}$

これらの結果を表-13，図-10 に示した。この場合も 特に分散性についての変化はみられず，ブランクテスト

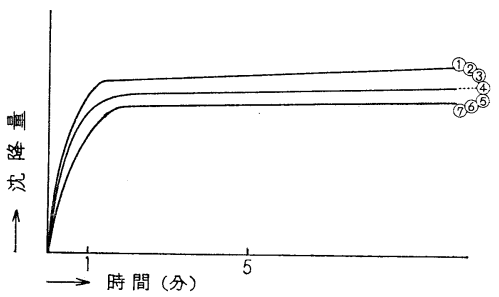

図-9 リグロイン中に和ける軽油ブラック の分散 30 分ギア

表-13 分散剤配合による分散順位

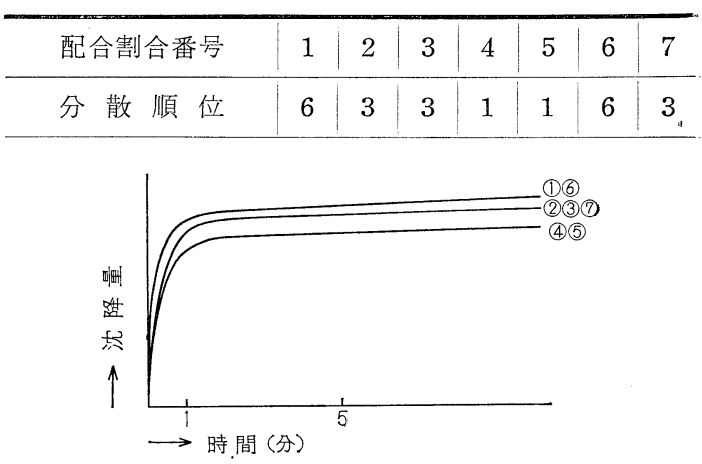

図-10 リグロイン中に持けるアントラセ ンブラックの分散 (A) 30 分ギア

の場合とほとえど変わらない。

ジアルキルジチオリン酸のナトリウム塩を添加するこ とによって凝集を起こし分散性が著しく低下する物質と， 分散性がよくなる物質とがあることがわかった。また， 塩の配合割合によっても分散の度合が変化するからこれ らの選択性を利用して鉣石の分離が可能となり浮遊選鉱 の目的が達せられることになる。

(昭和 38 年 11 月, 日本化学会中国四国支部松山大会: 講演)

正誤表 (38 巻 2 号)

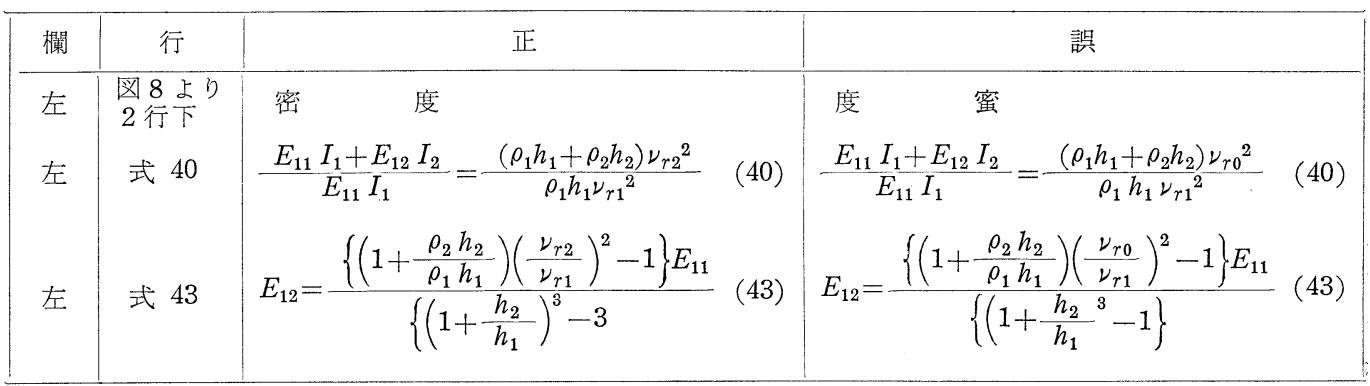

